\title{
Front Matter: Volume 8426
}

, "Front Matter: Volume 8426," Proc. SPIE 8426, Microstructured and Specialty Optical Fibres, 842601 (1 June 2012); doi: 10.1117/12.977713

SPIE. Event: SPIE Photonics Europe, 2012, Brussels, Belgium 


\section{PROCEEDINGS OF SPIE}

\section{Microstructured and Specialty Optical Fibres}


The papers included in this volume were part of the technical conference cited on the cover and title page. Papers were selected and subject to review by the editors and conference program committee. Some conference presentations may not be available for publication. The papers published in these proceedings reflect the work and thoughts of the authors and are published herein as submitted. The publisher is not responsible for the validity of the information or for any outcomes resulting from reliance thereon.

Please use the following format to cite material from this book:

Author(s), "Title of Paper," in Microstructured and Specialty Optical Fibres, edited by Kyriacos Kalli, Alexis Mendez, Proceedings of SPIE Vol. 8426 (SPIE, Bellingham, WA, 2012) Article CID Number.

ISSN 0277-786X

ISBN 9780819491183

Published by

SPIE

P.O. Box 10, Bellingham, Washington 98227-0010 USA

Telephone +1 3606763290 (Pacific Time) · Fax +1 3606471445

SPIE.org

Copyright () 2012, Society of Photo-Optical Instrumentation Engineers

Copying of material in this book for internal or personal use, or for the internal or personal use of specific clients, beyond the fair use provisions granted by the U.S. Copyright Law is authorized by SPIE subject to payment of copying fees. The Transactional Reporting Service base fee for this volume is $\$ 18.00$ per article (or portion thereof), which should be paid directly to the Copyright Clearance Center (CCC), 222 Rosewood Drive, Danvers, MA 01923. Payment may also be made electronically through CCC Online at copyright.com. Other copying for republication, resale, advertising or promotion, or any form of systematic or multiple reproduction of any material in this book is prohibited except with permission in writing from the publisher. The CCC fee code is 0277-786X/12/\$18.00.

Printed in the United States of America.

Publication of record for individual papers is online in the SPIE Digital Library.

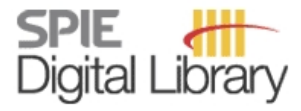

SPIEDigitalLibrary.org

Paper Numbering: Proceedings of SPIE follow an e-First publication model, with papers published first online and then in print and on CD-ROM. Papers are published as they are submitted and meet publication criteria. A unique, consistent, permanent citation identifier (CID) number is assigned to each article at the time of the first publication. Utilization of CIDs allows articles to be fully citable as soon as they are published online, and connects the same identifier to all online, print, and electronic versions of the publication. SPIE uses a six-digit CID article numbering system in which:

- The first four digits correspond to the SPIE volume number.

- The last two digits indicate publication order within the volume using a Base 36 numbering system employing both numerals and letters. These two-number sets start with 00, 01, 02, 03, 04 , $05,06,07,08,09,0 A, 0 B \ldots$. OZ, followed by 10-1Z, 20-2Z, etc.

The CID number appears on each page of the manuscript. The complete citation is used on the first page, and an abbreviated version on subsequent pages. Numbers in the index correspond to the last two digits of the six-digit CID number. 


\section{Contents}

xi Conference Committee

\section{SESSION 1 FIBRE MODIFICATION AND MICROSTRUCTURE INFILTRATION}

842602 Preparation and characterisation of optical fiber tips for nanoscopic applications (Invited Paper) [8426-01]

J. Bierlich, J. Kobelke, Institute of Photonic Technology (Germany); D. Brand, Univ. of Applied

Sciences (Germany); K. Kirsch, J. Dellith, H. Bartelt, Institute of Photonic Technology (Germany)

842603 Investigation on colloidal Te doped CdSe (CdSe:Te) quantum dots suspension in a liquid-core fiber [8426-02]

S. Pilz, Univ. Bern (Switzerland); V. Romano, Univ. Bern (Switzerland) and Bern Univ. of Applied Sciences (Switzerland)

842604 Formation of PDMS films inside the holes of silica photonic crystal fibers [8426-03] C. Markos, National Hellenic Research Foundation (Greece) and Univ. of Patras (Greece); K. Vlachos, Univ. of Patras (Greece); G. Kakarantzas, National Hellenic Research Foundation (Greece)

842605 Optical temperature switch based on microstructured fibre filled with different chemical mixtures [8426-04]

P. Marc, P. Piliszek, Military Univ. of Technology (Poland); M. Murawski, M. Szymanski,

T. Nasilowski, Military Univ. of Technology (Poland) and InPhoTech Ltd. (Poland);

L. R. Jaroszewicz, Military Univ. of Technology (Poland)

842606 Microstructure-assisted grating inscription in photonic crystal fibers [8426-05]

T. Baghdasaryan, T. Geernaert, F. Berghmans, H. Thienpont, Vrije Univ. Brussel (Belgium)

842607 Photonic bandgap guiding into a composite $\mathrm{AgPO}_{3}$-glass/silica microstructured optical fibre [8426-06]

I. Konidakis, G. Zito, S. Pissadakis, Foundation for Research and Technology-Hellas (Greece)

\section{SESSION 2 SPECIALITY FIBRE SENSORS I}

842609 Optical RI sensor based on an in-fiber Bragg grating Fabry-Perot cavity embedded with a micro-channel [8426-08]

Z. Yan, P. Saffari, K. Zhou, A. Adebay, L. Zhang, Aston Univ. (United Kingdom)

8426 OA Design of turn-around-point long-period gratings in Ge-doped photonic crystal fibers for evanescent sensing [8426-09]

J. Kanka, Institute of Photonics and Electronics of the ASCR, v.v.i. (Czech Republic)

8426 OB In-fiber temperature measurement during optical pumping of Yb-doped laser fibers [8426-10]

J. Fiebrandt, M. Leich, M. Rothhardt, H. Bartelt, Institute of Photonic Technology (Germany) 
8426 OC An FBG based hydrostatic pressure sensor for liquid level measurements [8426-11] D. Sengupta, M. Sai Shankar, P. Saidi Reddy, R. L. N. Sai Prasad, K. Srimannarayana, National Institute of Technology, Warangal (India)

\section{SESSION 3 SPECIALITY FIBRE SENSORS II}

8426 OD Fibre Bragg gratings written in highly birefringent microstructured fiber as very sensitive strain sensors (Invited Paper) [8426-12]

T. Tenderenda, M. Murawski, M. Szymanski, Military Univ. of Technology (Poland) and InPhoTech Ltd. (Poland); M. Becker, M. Rothhardt, H. Bartelt, Institute of Photonic Technology (Germany); P. Mergo, Marie Curie-Sklodowska Univ. (Poland); K. Poturaj, InPhoTech Ltd. (Poland) and Marie Curie-Sklodowska Univ. (Poland); M. Makara, Marie Curie-Sklodowska Univ. (Poland); K. Skorupski, InPhoTech Ltd. (Poland) and Marie Curie-Sklodowska Univ. (Poland); P. Marc, L. R. Jaroszewicz, Military Univ. of Technology (Poland); T. Nasilowski, Military Univ. of Technology (Poland) and InPhoTech Ltd. (Poland)

$8426 \mathrm{OE} \quad$ A grating-less in-fibre magnetometer realised in a polymer-MOF infiltrated using ferrofluid (Best Student Paper Award) [8426-13]

A. Candiani, Foundation for Research and Technology-Hellas (Greece) and Univ. degli Studi di Parma (Italy); A. Argyros, R. Lwin, S. G. Leon-Saval, The Univ. of Sidney (Australia); G. Zito, S. Selleri, Univ. degli Studi di Parma (Italy); S. Pissadakis, Foundation for Research and Technology-Hellas (Greece)

8426 OF Intensity curvature sensor based on photonic crystal fiber with three coupled cores [8426-14] H. Martins, M. B. Marques, INESC Porto (Portugal) and Univ. do Porto (Portugal); P. Jorge, INESC Porto (Portugal); C. M. B. Cordeiro, Univ. Estadual de Campinas (Brazil); O. Frazão, INESC Porto (Portugal)

8426 OG Strain characterization of suspended-core fiber tapers [8426-15]

R. M. André, S. O. Silva, INESC Porto (Portugal) and Univ. do Porto (Portugal); M. Becker, K. Schuster, M. Rothhardt, H. Bartelt, Institut für Photonische Technologien e.V. (Germany); M. B. Marques, INESC Porto (Portugal) and Univ. do Porto (Portugal); O. Frazão, INESC Porto (Portugal)

$8426 \mathrm{OH}$ Low power and inexpensive microstructured fiber Mach Zehnder interferometer as temperature insensitive mechanical sensor [8426-16] M. Murawski, M. Szymanski, Military Univ. of Technology (Poland) and InPhoTech Ltd. (Poland); Z. Holdynski, Military Univ. of Technology (Poland); T. Tenderenda, L. Ostrowski, Military Univ. of Technology (Poland) and InPhoTech Ltd. (Poland); K. Pawlik, InPhoTech Ltd. (Poland); K. Gossner, H. Krisch, Krohne Messtechnik GmbH \& Co. KG (Germany); P. Marć, L. R. Jaroszewicz, Military Univ. of Technology (Poland); T. Nasilowski, Military Univ. of Technology (Poland) and InPhoTech Ltd. (Poland)

8426 ol Active material for fiber core made by powder-in-tube method: subsequent homogenization by means of stack-and-draw technique (Invited Paper) [8426-17]

V. V. Velmiskin, O. N. Egorova, Fiber Optics Research Ctr. (Russian Federation);

V. Mishkin, K. Nishchev, Ogarev State Univ. (Russian Federation); S. L. Semjonov, Fiber Optics Research Ctr. (Russian Federation) 
8426 0J Flattened fundamental mode in microstructured fibers: design, realization and characterization [8426-18]

C. Valentin, Y. Quiquempois, G. Bouwmans, L. Bigot, M. Douay, A. Mussot, Lab. de Physique des Lasers, Atomes et Molécules, IRCICA, CNRS (France); L. Lago, P. Calvet, E. Hugonnot, Commissariat à l'Energie Atomique (France)

8426 OK The influence of the drawing process on the intrinsic stress in optical fibers and the arising possibility to optimize the birefringence of PM fibers [8426-19]

F. Just, M. Jäger, H. Bartelt, Institut für Photonische Technologien e.V. (Germany)

8426 OL Erbium doped low phonon glasses for application in up-conversion fiber lasers [8426-20] K. Anders, P. Florczyk, Institute of Microelectronics and Optoelectronics (Poland); R. Stepien, D. Pysz, Institute of Electronic Materials Technology (Poland); R. Piramidowicz, Institute of Microelectronics and Optoelectronics (Poland)

8426 OM Optical properties of Bi-doped Mg-Al silicate glasses and fibers [8426-21]

V. V. Velmiskin, Fiber Optics Research Ctr. (Russian Federation); B. I. Galagan,

B. I. Denker, S. E. Sverchkov, A. M. Prokhorov General Physics Institute (Russian Federation); S. L. Semjonov, S. V. Firstov, Fiber Optics Research Ctr. (Russian Federation); I. L. Shulman, A. M. Prokhorov General Physics Institute (Russian Federation); I. A. Bufetov, E. M. Dianov, Fiber Optics Research Ctr. (Russian Federation)

\section{SESSION $5 \quad$ TEST AND MEASUREMENT}

8426 ON Spectral interferometry-based dispersion characterization of microstructured and specialty optical fibers using a supercontinuum source (Invited Paper) [8426-22]

P. Hlubina, D. Ciprian, M. Kadulová, Technical Univ. of Ostrava (Czech Republic);

T. Martynkien, Wroclaw Univ. of Technology (Poland); P. Mergo, Maria Curie-Sklodowska Univ. (Poland); W. Urbańczyk, Wroclaw Univ. of Technology (Poland)

842600 Investigation of dispersion characteristics of highly nonlinear microstructured fibre series for customized supercontinuum generation [8426-23]

Z. Holdynski, Military Univ. of Technology (Poland); M. Szymanski, M. Murawski, Military Univ. of Technology (Poland) and InPhoTech Ltd. (Poland); P. Mergo, Maria Curie-Sklodowska Univ. (Poland); I. Merta, M. Gawronska, P. Marc, L. R. Jaroszewicz, Military Univ. of Technology (Poland); T. Nasilowski, Military Univ. of Technology (Poland) and InPhoTech Ltd. (Poland)

8426 OP Influence of high power $\mathbf{4 0 5} \mathbf{n m}$ multi-mode and single-mode diode laser light on the long-term stability of fused silica fibers [8426-24]

C. P. Gonschior, TH Mittelhessen (Germany) and City Univ. London (United Kingdom); K.-F. Klein, TH Mittelhessen (Germany); T. Sun, K. T. V. Grattan, City Univ. London (United Kingdom)

$84260 Q$ Mechanical reliability of microstructured optical fibers: a comparative study of tensile and bending strength [8426-25]

C. Sonnenfeld, S. Sulejmani, T. Geernaert, Vrije Univ. Brussel (Belgium); S. Eve, M. Gomina, CNRT Matériaux (France); M. Makara, K. Skorupski, P. Mergo, Marie Curie-Sklodowska Univ. (Poland); F. Berghmans, H. Thienpont, Vrije Univ. Brussel (Belgium) 
8426 OR An improved non-linear nearly-zero dispersion flattened photonic crystal fiber with the threefold symmetry core (Invited Paper) [8426-26]

R. Zeleny, M. Lucki, Czech Technical Univ. in Prague (Czech Republic)

8426 OS Characterization of the propagation in photonic crystal fibers with the scalar-finite element method [8426-27]

L. Cherbi, A. Bellalia, L. Bahloul, M. Touzene, M. Lamara, U.S.T.H.B. Univ. (Algeria)

8426 OT Design of a low-bending-loss large-mode-area photonic crystal fiber [8426-28]

M. Napierała, Vrije Univ. Brussel (Belgium) and Wroclaw Univ. of Technology (Poland);

E. Bereś-Pawlik, Wroclaw Univ. of Technology (Poland); T. Nasilowski, Military Univ. of Technology (Poland); P. Mergo, Marie Curie-Sklodowska Univ. (Poland); F. Berghmans,

H. Thienpont, Vrije Univ. Brussel (Belgium)

8426 OU Approximation of the effective refractive index of surface plasmons propagating along micron-sized gold wires in photonic crystal fibers [8426-29]

R. Spittel, M. Jäger, H. Bartelt, Institute of Photonic Technology (Germany)

$8426 \mathrm{OV}$ A low loss ultra-narrowband negative-dispersion and large mode field area photonic crystal fiber for dispersion compensation [8426-30]

Y. Zhang, Baoji College of Arts and Science (China) and Univ. of Glamorgan (United

Kingdom) and Xi'an Institute of Optics and Precision Mechanics (China); J. Huang, K. Li, Univ. of Glamorgan (United Kingdom); Y. Gong, Univ. of Glamorgan (United Kingdom) and Xi'an Institute of Optics and Precision Mechanics (China); N. J. Copner, Univ. of Glamorgan (United Kingdom)

\section{SESSION 7 FIBRE DESIGN AND NUMERICAL ANALYSIS II}

8426 OW On the influence of hexagonal lattice photonic crystal fiber parameters on femtosecond grating inscription (Invited Paper) [8426-31]

T. Baghdasaryan, T. Geernaert, F. Berghmans, H. Thienpont, Vrije Univ. Brussel (Belgium)

8426 0X Low-loss multimode interference couplers for terahertz waves [8426-32]

C. Themistos, Frederick Univ. (Cyprus); K. Kalli, Cyprus Univ. of Technology (Cyprus); M. Komodromos, C. Markides, Frederick Univ. (Cyprus); A. Quadir, B. M. A. Rahman, K. T. V. Grattan, City Univ. London (United Kingdom)

8426 OY Modeling of photonic crystal fiber with polymer inclusions [8426-33]

C. Markos, Univ. of Patras (Greece) and National Hellenic Research Foundation (Greece); K. Vlachos, National Hellenic Research Foundation (Greece); G. Kakarantzas, Univ. of Patras (Greece) 
842611 Brillouin fiber laser using As38Se62 suspended-core chalcogenide fiber (Invited Paper) [8426-36]

K. H. Tow, Univ. Européenne de Bretagne, Univ. de Rennes I (France) and FOTON, CNRS

(France); Y. Léguillon, Univ. Européenne de Bretagne, Univ. de Rennes I (France) and FOTON, CNRS (France) and Thales Underwater Systems (France); P. Besnard, Univ. Européenne de Bretagne, Univ. de Rennes I (France) and FOTON, CNRS (France); L. Brilland, PERFOS (France); J. Troles, P. Toupin, Univ. Européenne de Bretagne, Univ. de Rennes I (France) and Equipe Verres et Ceramiques, CNRS (France); D. Méchin, D. Trégoat, PERFOS (France); M. Doisy, Thales Underwater Systems (France)

842612 Enhanced stimulated Brillouin scattering in tellurite microstructured fibers [8426-37] R. Cherif, M. Zghal, Univ. of Carthage (Tunisia); M. Liao, Y. Ohishi, Toyota Technological Institute (Japan)

$842613 \mathrm{CW}$ parametric generation in polarization maintaining PCF pumped by Yb-doped fiber laser [8426-38]

E. A. Zlobina, Institute of Automation and Electrometry (Russian Federation); S. I. Kablukov, S. A. Babin, Institute of Automation and Electrometry (Russian Federation) and Novosibirsk State Univ. (Russian Federation)

842614 Development of large-core photonic crystal fiber for hyperspectral transmission [8426-39] R. Stepien, D. Pysz, I. Kujawa, Institute of Electronic Materials Technology (Poland); J. Pniewski, Univ. of Warsaw (Poland); A. J. Waddie, M. R. Taghizadeh, Heriot-Watt Univ. (United Kingdom); R. Buczynski, Institute of Electronic Materials Technology (Poland) and Univ. of Warsaw (Poland)

\section{SESSION 9 POLYMER FIBRES: DESIGN SENSORS AND APPLICATIONS}

842615 Novel block copolymers for multi-agent detection using polymer optical fibers [8426-40] L. Athanasekos, National Hellenic Research Foundation (Greece) and Univ. of Patras (Greece); S. Pispas, C. Riziotis, National Hellenic Research Foundation (Greece)

842616 Development of large core microstructured polymer optical fiber [8426-41]

A. Filipkowski, Institute of Electronic Materials Technology (Poland) and Heriot-Watt Univ. (United Kingdom); D. Pysz, Institute of Electronic Materials Technology (Poland); P. Gdula, K. Welikow, Warsaw Univ. of Technology (Poland); K. Harasny, Institute of Electronic Materials Technology (Poland); A. J. Waddie, Heriot-Watt Univ. (United Kingdom); K. Borzycki, National Institute of Telecommunications (Poland); A. Kraft, Heriot-Watt Univ. (United Kingdom); R. Piramidowicz, Warsaw Univ. of Technology (Poland); R. Stepien, Institute of Electronic Materials Technology (Poland); M. R. Taghizadeh, Heriot-Watt Univ. (United Kingdom); R. Buczynski, Institute of Electronic Materials Technology (Poland) and Univ. of Warsaw (Poland)

842617 Fiber design and realization of point-by-point written fiber Bragg gratings in polymer optical fibers [8426-42]

A. Stefani, Technical Univ. of Denmark (Denmark); M. Stecher, Philipps Univ. Marburg (Germany); G. E. Town, Macquarie Univ. (Australia); O. Bang, Technical Univ. of Denmark (Denmark) 
842618 An intrinsic biochemical concentration sensor using a polymer optical fibre Bragg grating [8426-43]

W. Zhang, D. J. Webb, Aston Univ. (United Kingdom); G.-D. Peng, Univ. of New South Wales (Australia)

842619 An investigation into the wavelength stability of polymer optical fibre Bragg gratings [8426-44] W. Zhang, A. Abang, D. J. Webb, Aston Univ. (United Kingdom); G.-D. Peng, Univ. of New South Wales (Australia)

8426 1A Microstructured plastic optical fibers for applications in FTTH systems [8426-45]

K. Welikow, Warsaw Univ. of Technology (Poland); P. Gdula, P. Szczepański, Warsaw Univ. of Technology (Poland) and National Institute of Telecommunication (Poland);

R. Buczyński, Institute of Electronic Materials Technology (Poland) and Univ. of Warsaw

(Poland); R. Piramidowicz, Warsaw Univ. of Technology (Poland)

\section{POSTER SESSION}

8426 1C Tellurite composite microstructured optical fibers with ultra-flattened and zero dispersion [8426-46]

Z. Duan, M. Liao, K. Tomas, H. Tong, K. Asano, T. Suzuki, Y. Ohishi, Toyota Technological Institute (Japan)

8426 1D All-fiber micro-machined Fabry-Perot strain sensor [8426-47]

S. Pevec, D. Đonlagić, Univ. of Maribor (Slovenia)

$84261 \mathrm{~F}$ A thermally scanned all-fiber interferometer based on vanadium-doped fiber [8426-49]

Ž. Matjašec, Univ. of Maribor (Slovenia); S. Čampelj, Optacore d.o.o. (Slovenia);

D. Đonlagić, Univ. of Maribor (Slovenia)

$84261 \mathrm{H} \quad$ Large-core microstructured fibers with asymmetric cladding design for practical single-mode operation [8426-51]

V. V. Demidov, S.I. Vavilov State Optical Institute (Russian Federation)

842611 Rare earth doped optical fiber fabrication by standard and sol-gel derived granulated oxides [8426-52]

D. Etissa, M. Neff, S. Pilz, M. Ryser, V. Romano, Univ. Bern (Germany)

$84261 \mathrm{~J}$ Dispersion properties of all-solid photonic crystal fibers with nanostructured core [8426-53] J. Pniewski, Univ. of Warsaw (Poland); D. Pysz, R. Stepien, I. Kujawa, Institute of Electronic Materials Technology (Poland); A. J. Waddie, M. R. Taghizadeh, Heriot-Watt Univ. (United Kingdom); R. Buczynski, Univ. of Warsaw (Poland) and Institute of Electronic Materials Technology (Poland) and Heriot-Watt Univ. (United Kingdom)

$8426 \mathrm{lL} \quad$ Mode conversion in hybrid optical fiber coupler [8426-55]

K. A. Stasiewicz, P. Marc, L. R. Jaroszewicz, Military Univ. of Technology (Poland)

$84261 \mathrm{M}$ Photonic sensor of liquids based on suspended-core fibres [8426-56]

B. Wajnchold, M. Grabka, S. Pustelny, W. Gawlik, Jagiellonian Univ. (Poland); P. Mergo, Marie Curie-Sklodowska Univ. (Poland) 
842610 Femtosecond and UV inscribed grating characterization in photonic crystal fibres: optimization for sensing applications [8426-58]

C. Koutsides, Cyprus Univ. of Technology (Cyprus) and Aston Univ. (United Kingdom);

E. Yiangou, Cyprus Univ. of Technology (Cyprus); C. Themistos, M. Komodromos, Frederick Univ. (Cyprus); P. Christodoulides, K. Kalli, Cyprus Univ. of Technology (Cyprus)

8426 IP Modeling microfluidic flow and heat transfer in circular and elliptical channels in microstructure fibres [8426-59]

P. Christodoulides, G. A. Florides, Cyprus Univ. of Technology (Cyprus); M. Komodromos, Frederick Univ. (Cyprus); K. Kalli, Cyprus Univ. of Technology (Cyprus)

Author Index 
Downloaded From: https://www.spiedigitallibrary.org/conference-proceedings-of-spie on 26 Apr 2023

Terms of Use: https://www.spiedigitallibrary.org/terms-of-use 


\title{
Conference Committee
}

\author{
Symposium Chairs \\ Francis Berghmans, Vrije Universiteit Brussel (Belgium) \\ Ronan Burgess, European Commission (Belgium) \\ Jürgen Popp, Institut für Photonische Technologien e.V. (Germany) \\ Peter Hartmann, SCHOTT AG (Germany)
}

Honorary Symposium Chair

Hugo Thienpont, Vrije Universiteit Brussel (Belgium)

Conference Chairs

Kyriacos Kalli, Cyprus University of Technology (Cyprus)

Alexis Mendez, MCH Engineering LLC (United States)

Programme Committee

Jean-Luc Adam, Université de Rennes 1 (France)

Miguel V. Andrés, Universitat de València (Spain)

John Ballato, Advanced Materials Center (United States)

Ole Bang, Technical University of Denmark (Denmark)

Hartmut Bartelt, Institut für Photonische Technologien e.V. (Germany)

Aurelien Bergonzo, Draka Comteq France (France)

Neil G. Broderick, The University of Auckland (New Zealand)

Benjamin J. Eggleton, The University of Sydney (Australia)

Christopher Emslie, Fibercore Ltd. (United Kingdom)

Sébastien Février, XLIM Institut de Recherche (France)

Jiri Kanka, Institute of Photonics and Electronics of the ASCR, v.v.i.

(Czech Republic)

Jonathan C. Knight, University of Bath (United Kingdom)

Hanne Ludvigsen, Aalto University School of Science and Technology (Finland)

Walter Margulis, Acreo AB (Sweden)

Saeed Rehman, Fibertronix AB (Sweden)

Valerio Romano, Berner Fachhochschule Technik und Informatik (Switzerland)

Kay Schuster, Institut für Photonische Technologien e.V. (Germany)

Waclaw Urbanczyk, Wroclaw University of Technology (Poland)

David J. Webb, Aston University (United Kingdom)

Alexei M. Zheltikov, Lomonosov Moscow State University (Russian Federation) 
Session Chairs

1 Fibre Modification and Microstructure Infiltration

Kyriacos Kalli, Cyprus University of Technology (Cyprus)

2 Speciality Fibre Sensors I

Kyriacos Kalli, Cyprus University of Technology (Cyprus)

3 Speciality Fibre Sensors II

David J. Webb, Aston University (United Kingdom)

$4 \quad$ Novel Fibre Fabrication

Kyriacos Kalli, Cyprus University of Technology (Cyprus)

5 Test and Measurement

Hartmut Bartelt, Institut für Photonische Technologien e.V. (Germany)

6 Fibre Design and Numerical Analysis I

Kyriacos Kalli, Cyprus University of Technology (Cyprus)

$7 \quad$ Fibre Design and Numerical Analysis II

Jiri Kanka, Institute of Photonics and Electronics of the ASCR, v.v.i.

(Czech Republic)

$8 \quad$ Mid-IR Sources and Nonlinearities

David J. Webb, Aston University (United Kingdom)

9 Polymer Fibres: Design Sensors and Applications

Kyriacos Kalli, Cyprus University of Technology (Cyprus) 